Original Research Paper

\title{
Gully Erosion Rate Assessment at the Choqazanbil Temple Using GIS Methods
}

\author{
Hadi Jarahi \\ Department of Geosciences, North Tehran Branch, Islamic Azad University (IAU), Tehran, Iran
}

\section{Article history}

Received: 04-05-2017

Revised: $12-07-2017$

Accepted: 06-11-2017

Email: hadijarahi@gmail.com

\begin{abstract}
The Choqazanbil temple located at $60 \mathrm{~km}$ of south west of shush city in the south west of Iran. This temple with 3500 years archaism is one of the oldest historical titles in Iran. The temple position is close to the Sardarabad anticline with Neogene to Quaternary deposits. Many news about damaging of ancient buildings are reported most recently. This report shows that stream erosion can excavate the land of temple up to $2 \mathrm{~m}$. The aim of this study is to determine the rate of erosion around the Choqazanbil temple using GIS methods. We select one of streams in the western templeside. Aerial Photos and satellite imagery from 1951 to 2014 was collected for use in GIS calculations. The results of this study shown that gully erosion rates take increased over time. The average rate is $18.2 \mathrm{~m} / \mathrm{y}$. In next years, this value of gully erosion can make irrecoverable damages to the Choqazanbil temple.
\end{abstract}

Keywords: Choqazanbil Temple, Gully Erosion, Shush City, Quaternary Deposits

\section{Introduction}

Iran with more the 12000 years of civilization, is one of the most ancient countries in the world (Abrahamian, 2008; Foltz, 2015). However, preservation and restoration of the remaining workson the history of this country have always been far from the authorities'eyes. Perhaps remnants of a civilization with a history of several thousand years, with costs and archaeologists carefully and with years of hard work brought the earthout, but over the decades, the atmospheric effects and disappears completely destroyed. Choqazanbil civilization (Foltz, 2015) is one of these cases that considered in this study. The most important dangers around Choqazanbil temple is Gully erosion. Gully erosion, the most impressive and striking erosion type, has been recognized as one of the major global environmental problems (Poesen et al., 2003). Gully erosion is the removal of soil along drainage lines by surface water runoff (MPORG, 2009). Once started, gullies will continue to move by head ward erosion or by slumping of the side walls (Abdulfatai et al., 2014). In recent years, gully erosion is going to destroy the body of temple and other ancient mansions.

\section{Study Area}

The temple, is located at $60 \mathrm{~km}$ of south of Shush city and the western coast of Dez river. This temple was a most fortified city in its time and protected using 3 circular walls with more than $20 \mathrm{~m}$ height Fig. 1. The wall length in order from outside to inside is 1200,450 and $130 \mathrm{~m}$ (Mahmoudi et al., 2015; NAT, 2011). Temple area drains with several streams that its twigs are located near this ancient place. Gully erosion caused by atmospheric agents (Albert et al., 2006), excavated the stream bed and made deepening and expansion drainages in the temple area Fig. 2.

\section{Materials and Methods}

Erosion is surface processes that sculpture the earth's landscape and constitutes one of the global environmental problems. Soil erosion is perhaps the most serious mechanism of land degradation in the tropics (El-Swaify et al., 1982). However, gully is visually the most impressive of all types of erosion (ElSwaify, 1990). Gully erosion is a well-defined water worn channel (Monkhouse and Small, 1978). In this part of study, we want to calculate the gully erosion rate. Gully erosion started in the past. So we should have data for a wide range of time. Therefore, we select the GIS method to do the study. Aerial photographs from 1951 to 2014 are available Fig. 3. As a first step, this photograph should be geo referenced using Arc GIS. We used Quick Bird Satellite imagery to create reference points. Then, the trace of gullies should digitized. After digitizing each part of gullies, the gully length is accessible. This process should be performed on all Photographs. 


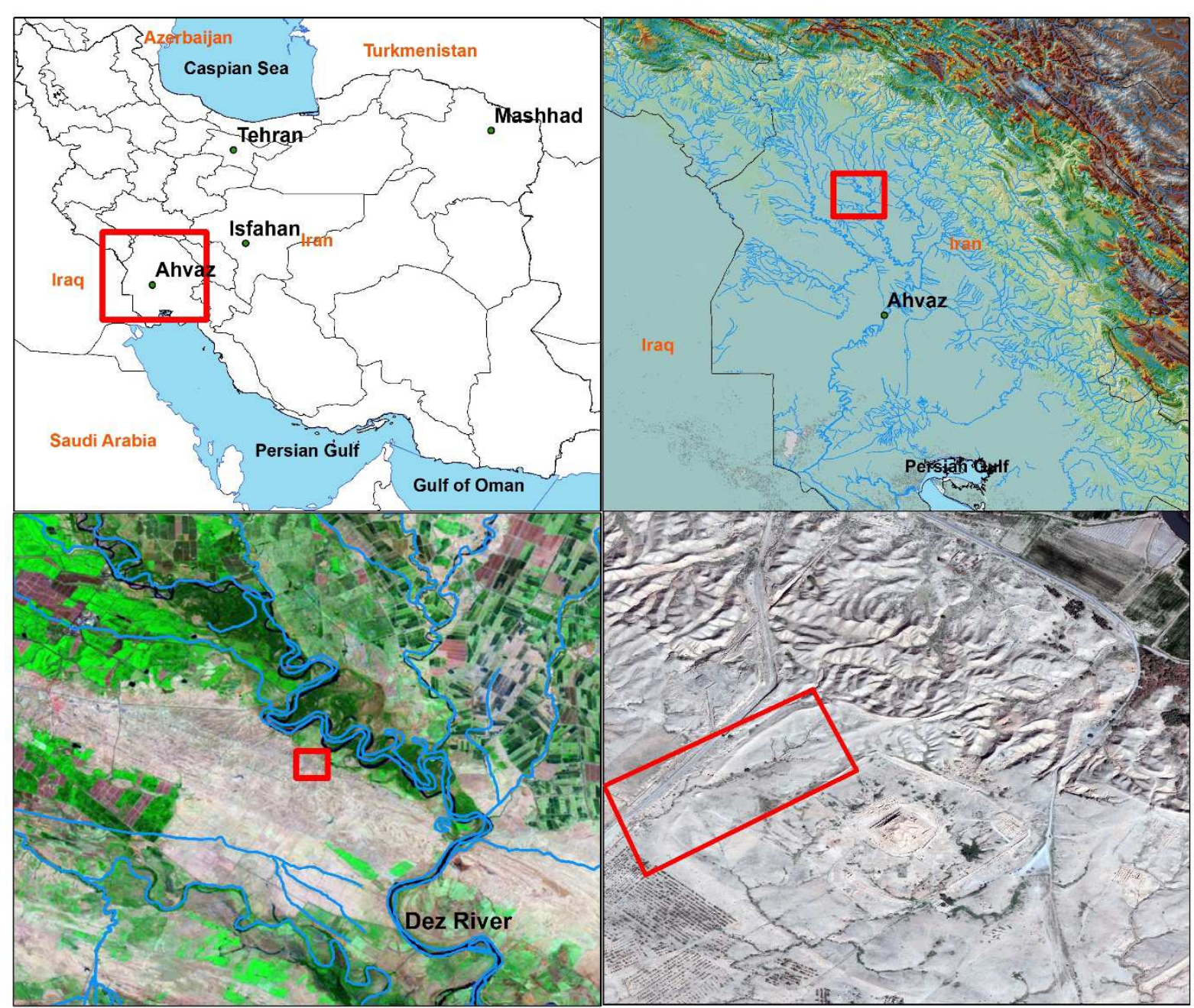

Fig. 1: Study area showed on a GIS map

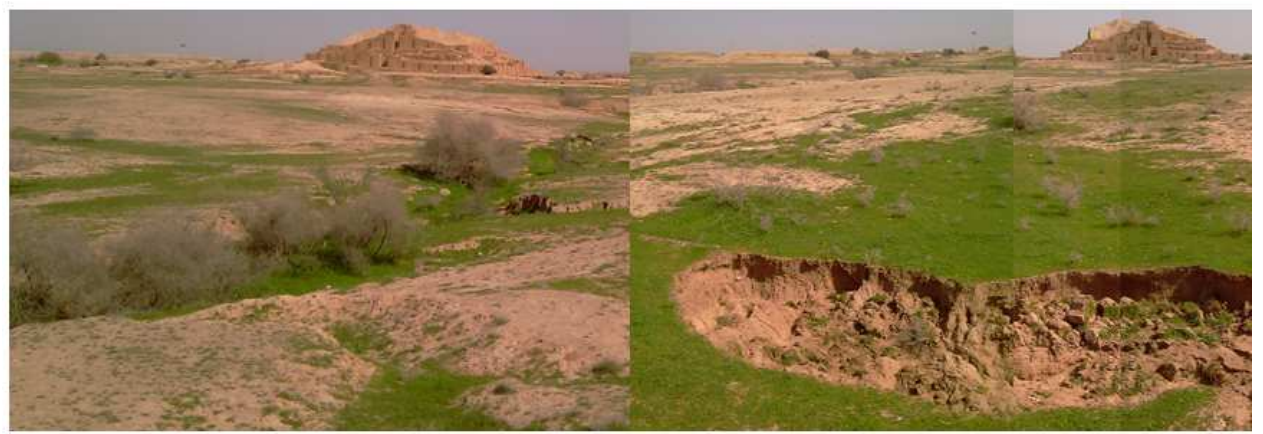

Fig. 2: Sample of Gully erosion in the Choqazanbil temple area of selected stream

\section{Determining Gully Erosion Rate}

As it mentioned, we used Aerial photographs that are taken in 1951, 1966, 1993, 2006, 2011 and 2014. These images covered 63 years of erosion time. After digitizing the photographs, trend of gullies developments was founded Fig. 4. The results of GIS measurements are in Table 1. Figure 5 was made for better understanding of Table 1 data's. Base on this data's, the gully erosion rate take increase by time. The minimum value is $5.5 \mathrm{~m} / \mathrm{y}$ that is for 1951 and the maximum value (29) calculated for 2014 . The average gully erosion rate is $18.2 \mathrm{~m} / \mathrm{y}$. 


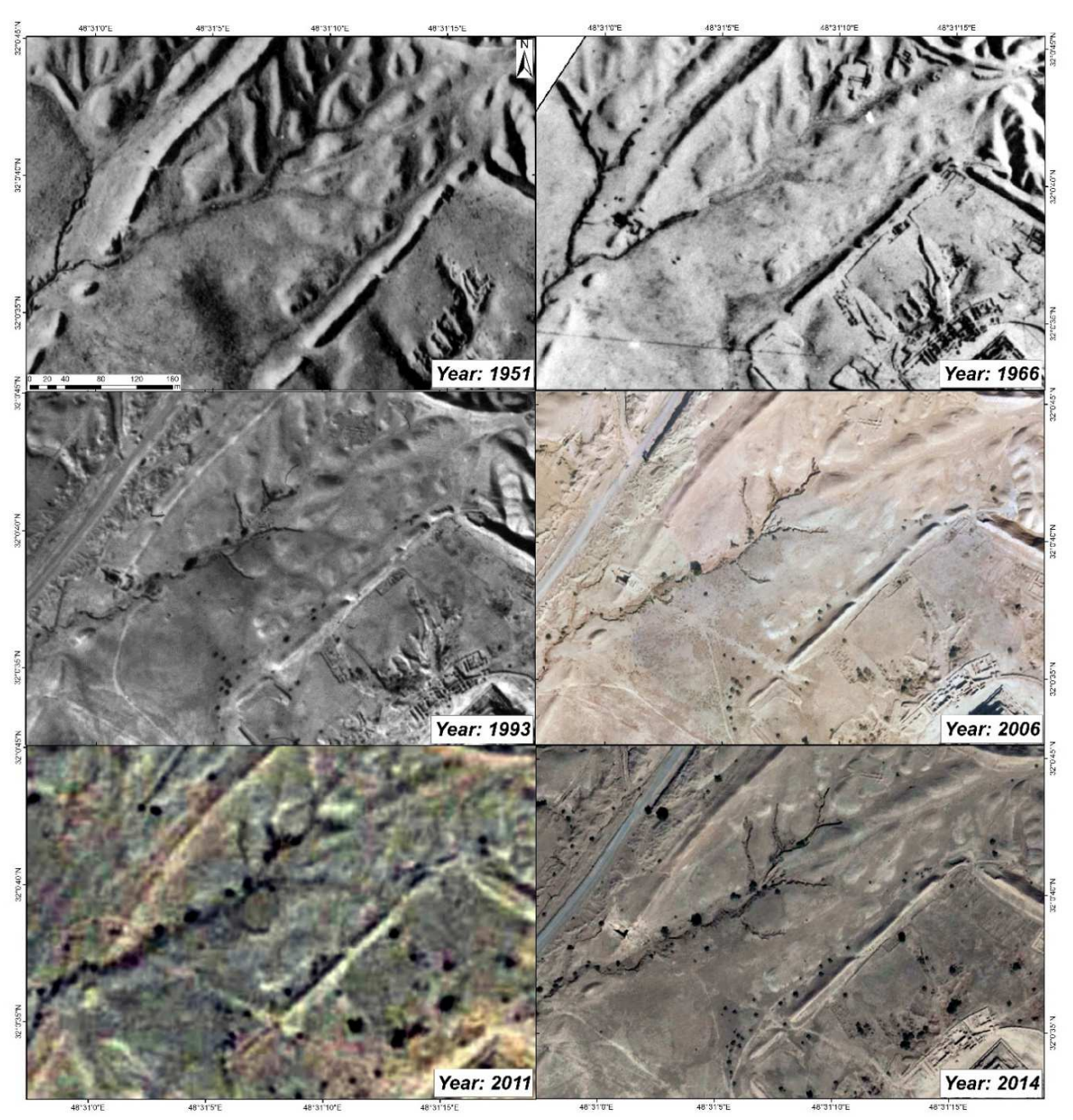

Fig. 3: Gully erosion shown in Aerial Photograph from 1951 to 2014

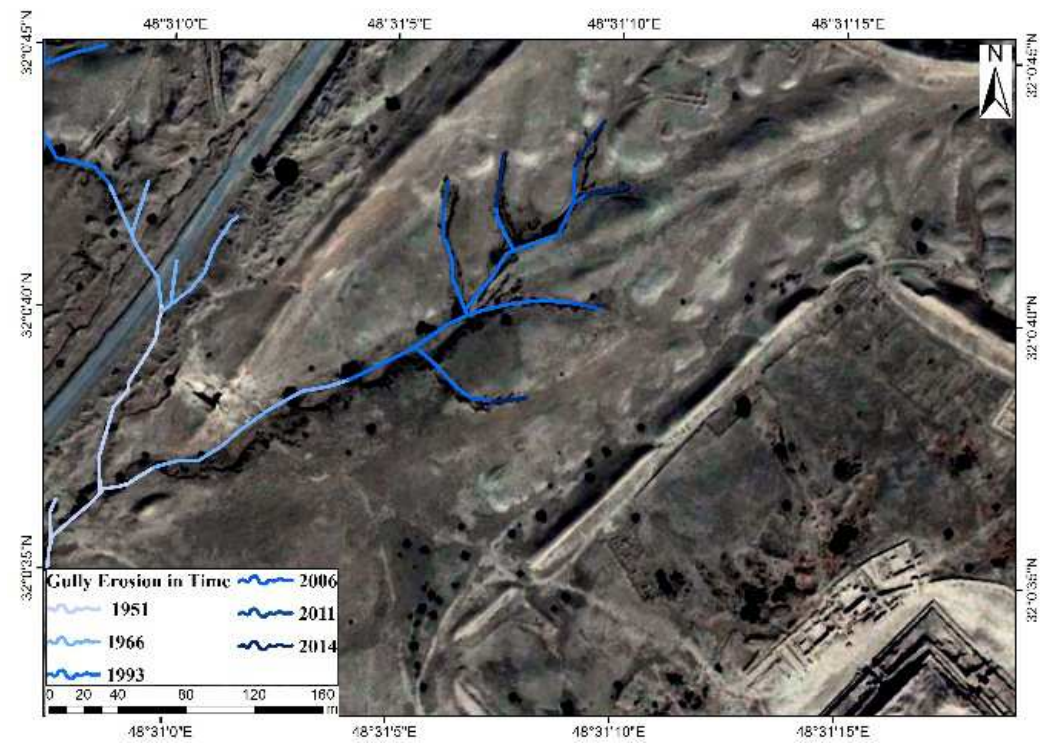

Fig. 4: The gully erosion trend shown by green tone colors from 1951 to 2014 


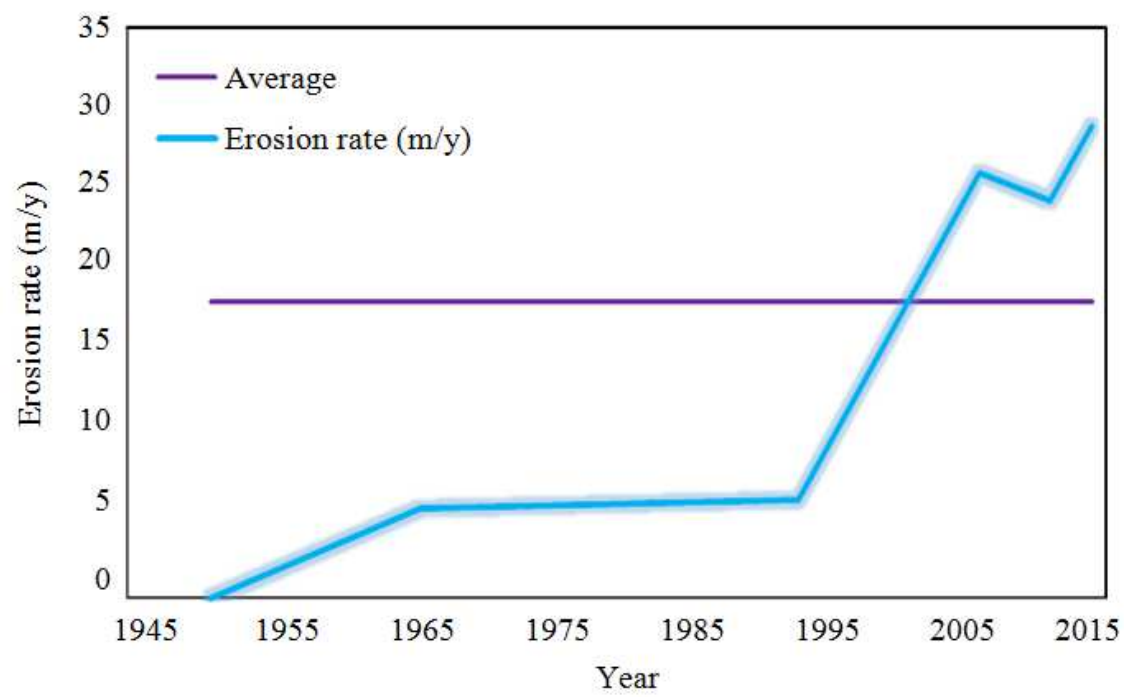

Fig. 5: Chart of erosion rate change

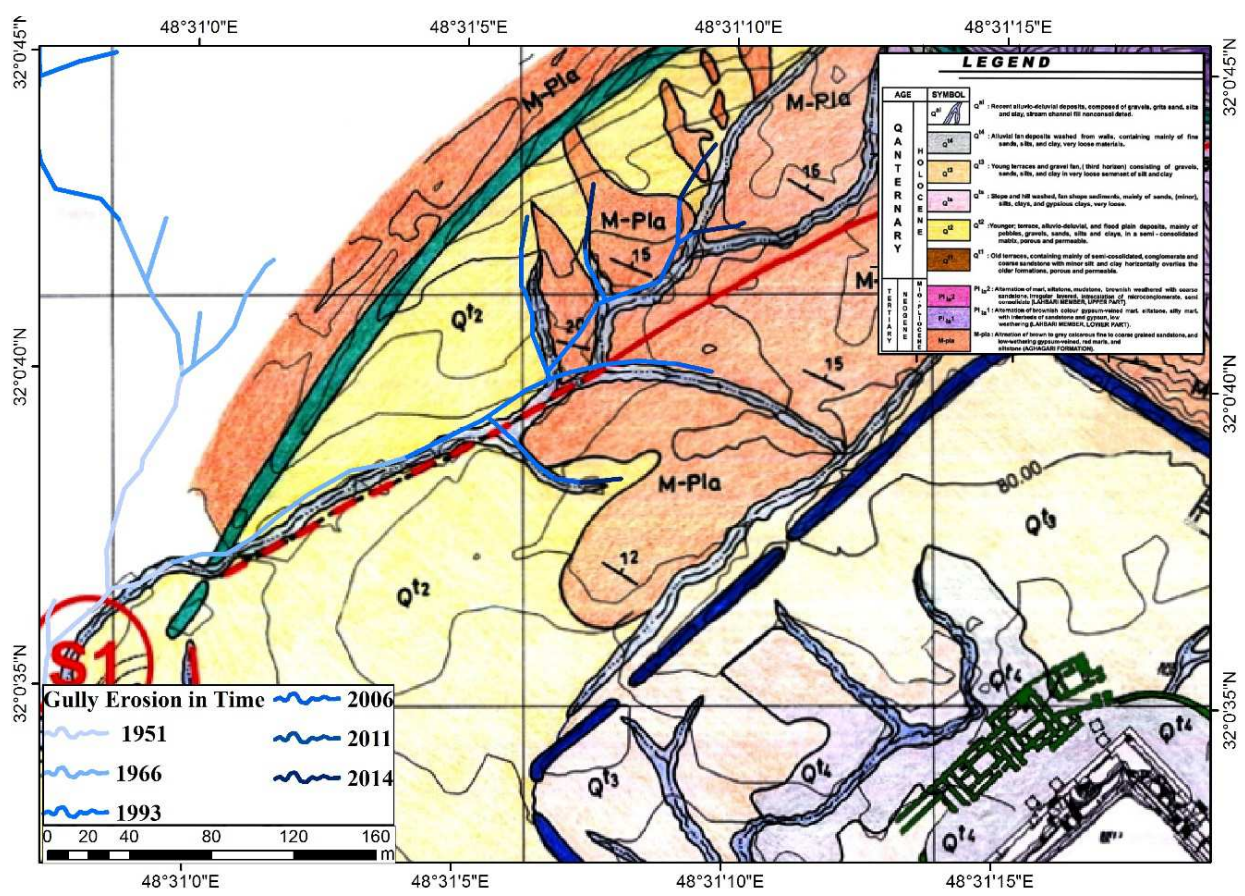

Fig. 6: Geological map of Choqazanbil temple (Jarahi, 2013)

Table 1: The value of erosion rate in choqazanbil temple

\begin{tabular}{llll}
\hline & Average & & \\
Erosion rate $(\mathrm{m} / \mathrm{y})$ & $-\mathrm{c}$ & & \\
\hline 0 & Period (year) & Erosion $(\mathrm{m})$ & Imaging date \\
5.5 & 0 & 33 & 1951 \\
6.1 & 15 & 83 & 1966 \\
26 & 27 & 165 & 2006 \\
24.4 & 13 & 339 & 2011 \\
29 & 5 & 122 & 2014 \\
18.2 & 3 & 87 & Sum \\
\hline
\end{tabular}




\section{Effective Parameters on Erosion Rate}

The erosion rate from 1965 to 1993 , is about 5.5 (for 28 years). But from 1993 to 2006 (for 13 years), this value has increased five times. Changing atthe gully erosion rate caused by two main parameters; climate changing and geological units change. In the short period (about 3000 years), the climate can't change. To check the geological parameter, we used the geology map Fig. 6 of Choqazanbil temple (Jarahi, 2013; Perry and Setudehnia, 1967). As it is shown in Fig. 6, before 1993 the activation of gully erosion take location in $\mathrm{Q}^{\mathrm{t} 2}$ deposits with more than $200 \mathrm{~m}$ thickens. The constituent materials of this unit include moderate compacted gravel, sand and silt with low permeability. After 1993, the gully continues its erosion in M-Pla units. Deposits of this unit are alternately of marl and gypsum-bearing sandstone, with a poor degree of compaction. Therefore, change in geological unit can be the main effective parameters in association with increasing gully erosion rate.

\section{Discussion and Conclusion}

The hazard of gully erosion is threatening the Choqazanbil temple. This kind of erosion can excavate the earth up to $2 \mathrm{~m}$. We used Aerial photography from 1951 to 2014 to calculate the rate of erosion. Based on results, the average rate is about $18.2 \mathrm{~m} / \mathrm{y}$. From 1993 to 2006, the rate value increased five times. According to geological studies, changing of units is the effective factor to change the gully erosion rate. It is expected in future years, this kind of erosion makes irretrievable damages to the Choqazanbil temple.

\section{Acknowledgement}

The author expresses his appreciation of the NAT consulting engineering company, in order to provide facility for field studies. In addition, special thanks to Dr. Sadegh Partani due to his valuable guidance in this research.

\section{Ethics}

This article is original and contains unpublished materials. The corresponding author confirms that all of the other authors have read and approved the manuscript and there are no ethical issues involved.

\section{References}

Abdulfatai, I.A., I.A. Okunlola, W.G. Akande, L.O. Momoh and K.O. Ibrahim, 2014. Review of gully erosion in Nigeria: Causes, impacts and possible solutions. J. Geosciences Geomatics, 2: 125-129.

Abrahamian, E., 2008. A History of Modern Iran. 1st Edn., Cambridge University Press, Cambridge, ISBN-10:0521821398, pp: 260.
Albert, A.A., A.A. Samson, O.O. Peter and A.O. Olufunmilayo, 2006. An assessment of the socio economic impacts of soil erosion in South-Eastern Nigeria, shaping the change. Congress Munich, Germany.

El-Swaify, S.A., E.W. Dangler and C.L. Armstrong, 1982. Soil erosion by water in the tropics. Univ. Hawaii/HITAHR-CTAHR Res. Extension Series, 24: 173-173.

El-Swaify, S.A., 1990. Research needs and applications to reduce erosion and sedimentation in the tropics. IAH-AISH Publication, 192: 3-13.

Foltz, R., 2015. Iran in World History. 1st Edn., Oxford University Press, New York, ISBN-10: 0199335508, pp: 151 .

Jarahi, H., 2013. Geological report of Choqazanbil Temple area, Naghsh Avaran Tous co.

Mahmoudi, M.A., S. Partani, N. Partani, M. Asgharzadeh and H. Jarahi et al., 2015. Hydraulic modelling and erosion vulnerability with historical approach in eastern ancient civilization, Ilamian/Susa Civilization in UNESCO World Heritage, CHOQA Zanbil, 3200 BC. IAHR World Congress, Mississippi .

Monkhouse, F.J. and J. Small, 1978. A Dictionary of the Natural Environment. 1st Edn., Arnold, London.

MPORG, 2009, Basic design forerosion control in streams and channels structures office of deputy for strategic supervision bureau of technical execution systems No. 417.

NAT, 2011. Topographic map of Choqazanbil Temple, 1/2000 scale. Naghsh Avaran Tous Co.

Perry, J.T. and A. Setudehnia, 1967. Geological map of Shushtar, Scale: 1/100.000, Iranian Oil Operating Companies, sheet No.20820E.

Poesen, J., J. Nachtergaele, G. Verstraeten and C. Valentin, 2003. Gully erosion and environmental change: Importance and research needs. Catena, 50: 91-133. 